
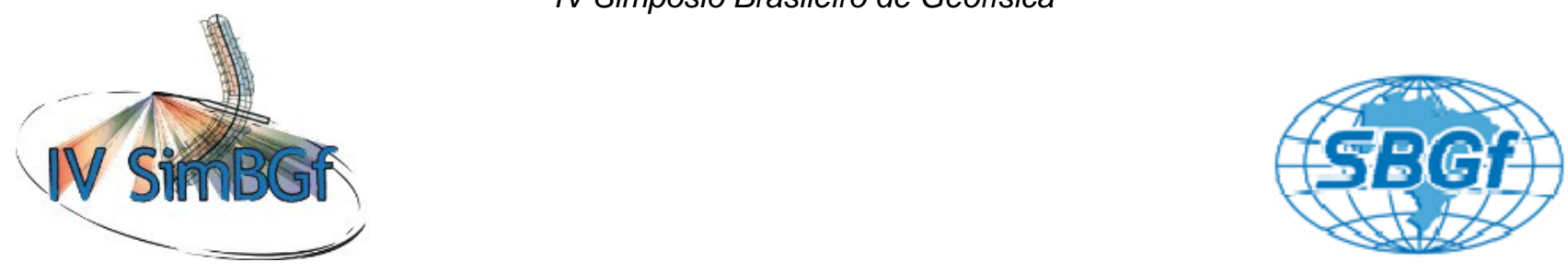

\title{
Integration of High Resolution Falcon Gravity Gradiometry and Seismic data: an example from Northern Argentina.
}

Marcela Lidia Fernandez, Petrobras Energia, Argentina, Julio Cesar Soares de Oliveira Lyrio, Petrobras, Brazil

Luiz Braga*, S. V. (Rao) Yalamanchili and Alan Morgan, Fugro Gravity and Magnetic Services, Houston, TX, USA

Copyright 2008, SBGf - Sociedade Brasileira de Geofísica

Este texto foi preparado para a apresentação no IV Simpósio Brasileiro de Geofísica Belém, 14 a 17 de novembro de 2010. Seu conteúdo foi revisado pelo Comitê Técnico do IV SimBGf, mas não necessariamente representa a opinião da SBGf ou de seus associados. É proibida a reprodução total ou parcial deste material para propósitos comerciais sem prévia autorização da SBGf

\section{SUMMARY}

Integrated interpretation of high resolution FALCON airborne gravity gradient and magnetic data with 2D seismic data from the Chirete Block, onshore northern Argentina, provided enhanced understanding of the tectonic framework, basement configuration, and sedimentary structures.

Basement related faults/lineament maps were generated using several enhancements of gravity gradient and magnetic data. These were combined with magnetic depth estimates, seismic and gravity to create an integrated 3D basement model.

Seismic depth sections, velocities, and well logs from nearby discoveries, were used as constraints for $2.5 \mathrm{D}$ and 3D gravity and magnetic modeling. This enabled key sedimentary features to be identified and mapped both along and between existing seismic lines.

Several igneous provinces were identified, and are probably related to the rift and post-rift periods.

A strong correlation exists between faults derived independently from seismic reflection data and enhanced Airborne Gravity Gradiometer data.

A number of structural features were identified with the mapped faulting, which may provide new targets for further interpretation or drilling

Key words: airborne gravity gradient-seismic-magnetic.

\section{INTRODUCTION}

Fugro Gravity and Magnetic Services (FGMS) was contracted by Petrobras to interpret airborne magnetic and gravity gradiometer data in the Chirete Block area of Argentina. (Figure 1). These data were acquired with a flight line spacing of $145 \mathrm{~m}$ for magnetic data and $290 \mathrm{~m}$ for the gravity data. The survey production period was from February to June 2008. The survey area covers approximately $35 \mathrm{~km}$ in an east-west direction and 105 $\mathrm{km}$ from south to north. One must first understand the area's geological overview, including its tectonic framework, stratigraphic framework and petroleum systems.

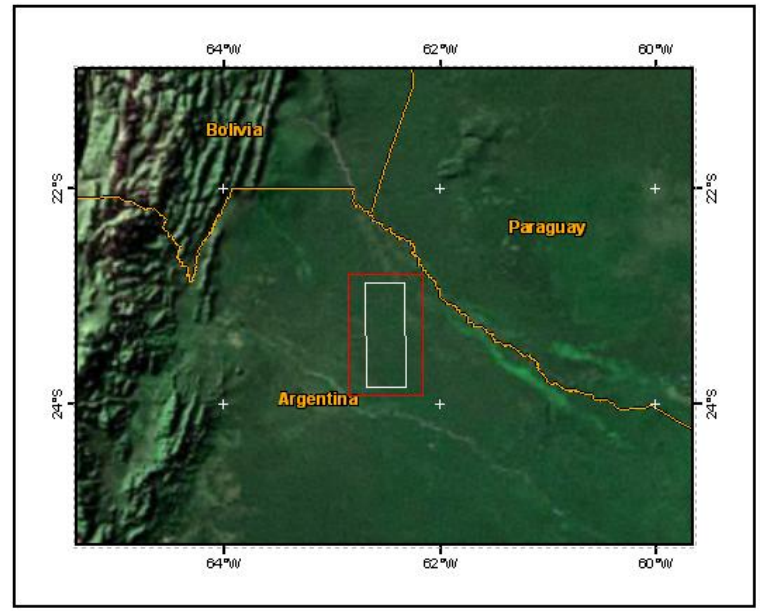

Figure 1: Study area location map

The tectonic framework has four events with the reactivation of pre-existing structures from the Late Precambrian to the Late Cretaceous periods. The result of the Pampean Orogeny was the closure of the Puncoviscan Ocean. Next, the Chanic Orogeny was related to the major South American subduction. Rifting and opening of the South Atlantic followed (Cominguez \& Ramos, 1995, Jacques, 2003). Finally, the Andean Orogeny occurred, producing a retro-arc foreland basin along the eastern margin of the Andes.

Pre-rift, syn-rift and post-rift sedimentation characterized the stratigraphic framework from the Precambrian to the early Tertiary. (Cominguez \& Ramos, 1995.) Pre-rifting deposited foreland basin clastics. During the rift, both siliciclastic and volcanic sedimentation occurred. A sag phase with a wide variety of lithologies and a good seismic marker characterizes the post-rift.

Both clastics and carbonates comprise the main petroleum system. These are sandstones, oolitic limestones and fractured limestone in the Yacoraite Formation in which are shown in a simplified stratigraphic section in Figure 2. 


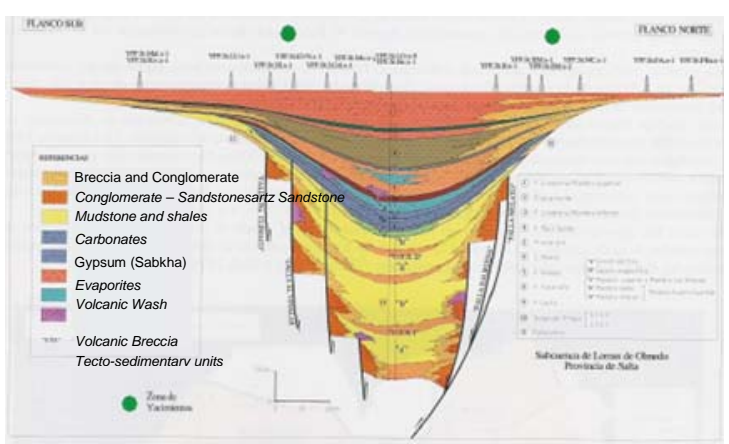

Figure 2: Stratigraphic section of the Lomas de Olmedo rift. (Modified from Hernández, Boll and Gómez Omil 1999).

\section{METHOD AND RESULTS}

\section{Objectives}

The primary objective was to map the magnetic basement and associated major structural elements. This was for the purpose of evaluating potential prospects for oil-andgas exploration. A secondary objective included the identification of igneous features within the sedimentary section.

\section{Data Processing and Enhancements}

Gravity, magnetic, elevation, seismic and wire-line data were incorporated in the interpretation. Airborne gravity gradiometry (AGG) in conjuction with high-resolution aeromagnetic (HRAM) data were acquired and processed. Seismic data provided structural modeling constraints while the wire-line data constrained densities.

The processing included standard leveling and corrections for gravity and magnetics. Bouguer and terrain corrections were made for gravity data ( $g_{D}$ and $\mathrm{G}_{\mathrm{DD}}$ ). (Figures $3 \mathrm{~A}$ and $3 \mathrm{~B}$ ) After leveling of the total magnetic intensity (TMI) anomaly (Figure $3 \mathrm{C}$ ), reduction to the magnetic pole (RTP) transformation was applied for the magnetic data (Figure 3D).

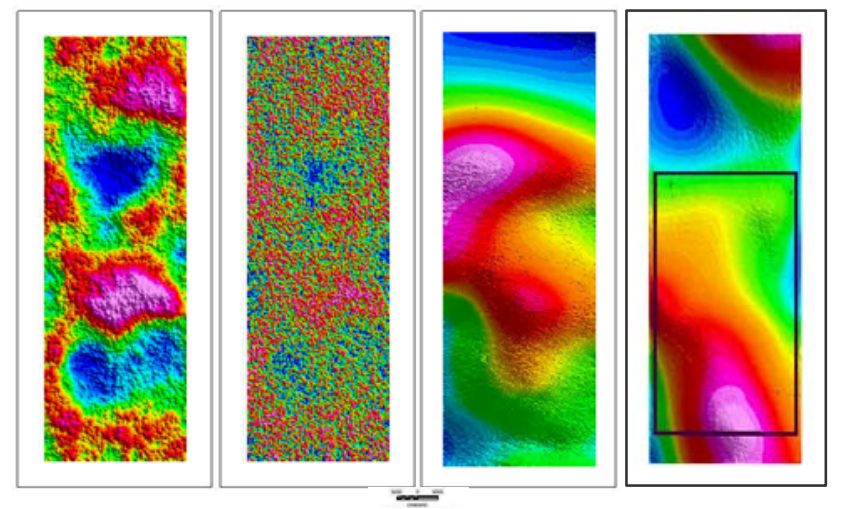

Figure 3A-D (Left to Right). Red colors in the grid images indicate higher values while blue colors indicate lower values. A) Bouguer gravity anomaly $\left(g_{D}\right)$. B) Vertical gravity gradient $\left(\mathrm{G}_{\mathrm{DD}}\right)$. C) Total Magnetic Intensity (TMI) anomaly. D) Reduced to Pole (RTP) magnetic anomaly. $A$ box on Figure 3D shows the outline of Figure $5 A-D$

Werner deconvolution, Euler deconvolution and Peters half slope methods were applied to the magnetic data for magnetic basement depth estimation. Every line of the data was interpreted and the depths to the magnetic basement were checked for the consistency from line to line data before contouring the basement surface. The estimation resulted in depths between $4 \mathrm{~km}$ and $13.5 \mathrm{~km}$ below sea level with major East-West bounding faults. Igneous structures were inferred from enhancements of the RTP data.

Enhancements were made to the gravity and magnetic data including band-pass, derivatives with one or more transformations. The enhanced AGG data critically supplemented enhanced magnetic data for the identification of linear anomalies arising from shallow sedimentary sources as well as from deeper basement sources

\section{D, 2.5D and 3D Modeling}

Seven 2D/2.5D magnetic and gravity models supported and adjusted the interpretation of the seismic sections. One model, along seismic section 1270 crosses one of the major bounding faults of the Lomas de Olmedo rift (Figure 4). The wide range of densities (2.67 to 2.87 $\mathrm{g} / \mathrm{cm}^{3}$ ) and magnetic susceptibilities (500 to 5000 microcgs units) in the basement support a change in the crustal

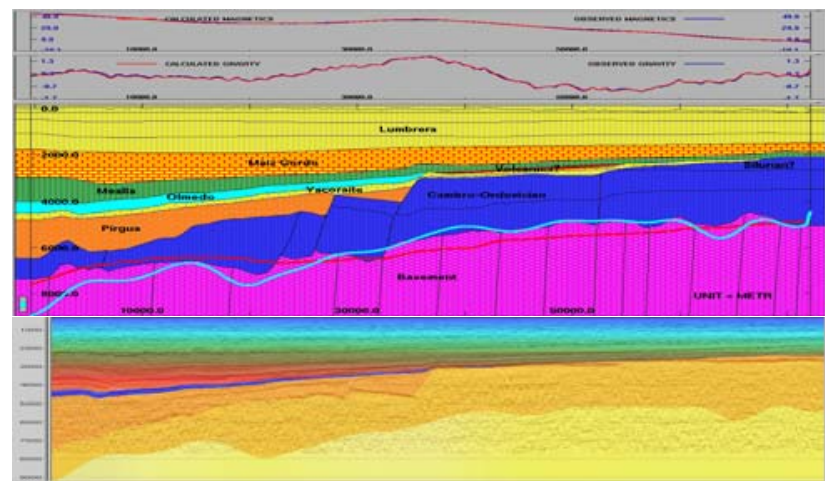

type from felsic to mafic lithologies.

Figure 4. 2D model line 1270 (Top) and seismic section 1270

(Bottom). This NNW-SSE oriented line transects the southern-most bounding fault of the Lomas de Olmedo rift. Color shading over the seismic image reflects density values from the 3D model.

3D gravity modeling was performed and was initially constrained by formations from well tops, seismicinterpreted horizons, magnetic depth estimates and logged density or velocity measurements from wells. 
One particular enhancement of the AGG data stands out when compared to the geometry of the acoustic basement from seismic reflection data. When a bandpass of 5 to $30 \mathrm{~km}$ was applied to the AGG vertical derivative of the gravity gradient $\left(G_{D D}\right)$, a striking correlation was made with the shape of the enhanced data and the acoustic basement surface from seismic reflection data (Figures 5A and 5B).

3D modeling occurred in three stages designed to emulate effect of a 5-30 km band-pass of the Bouguer gravity data $\left(g_{D}\right)$ by inverting short-wavelength to the density variation in the shallow sedimentary section and long wavelength to the density variation within the basement. The 3D potential field interpretation resembles the acoustic in structural shape and location, but is somewhat deeper (Figures 5C and 5D).
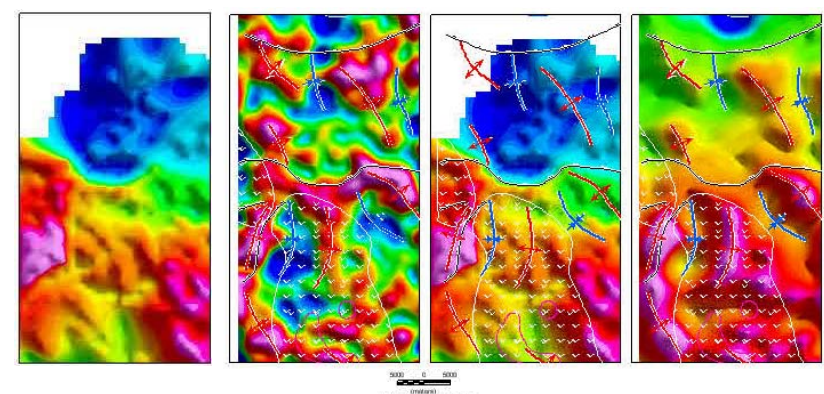

Figure 5A-D (Left to Right). A) Acoustic basement depth from seismic reflection data (depth range 3.2 to $5.8 \mathrm{~km}$ ). B) $5-30 \mathrm{~km}$ band-pass of the $\mathrm{G}_{\mathrm{DD}}$ Bouguer gravity anomaly. C) Acoustic basement depth showing interpreted structural elements. D) Basement resulting from 3D inversion showing interpreted structural elements. Red colors in the grid images indicate shallower depths while blue colors indicate deeper depths.

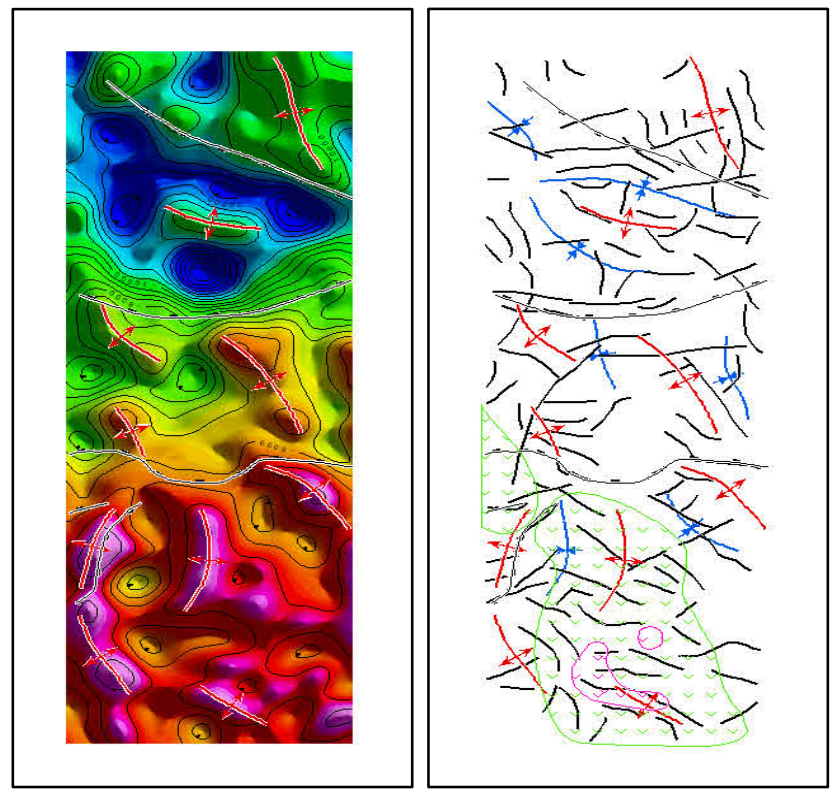

Figure 6A-B (left to right): A) Depth to the basement with major structural elements overlay. The contours are with 500 meters interval. B) Tectonic elements map derived from several enhancements of gravity gradient and magnetic data.

The depth to the basement and tectonic elements are shown in Figures 6A and 6B. The primary structural trends are of ENE-WSW and NNW-SSE orientations. These trends are intersected by faults, which were in perpendicular orientation at several locations, and displacements along strike are apparent. The dominant basement related faults are approximately following eastwest trends where as faults within the sedimentary section exhibit north northwest and north northeast trends.

Several significant basement structural lows and structural highs are identified. Magnetic sources within the sedimentary section are also identified, and these are mapped as volcanic zones. These zones are shown with green and pink colors in Figure 6B.

\section{CONCLUSIONS}

Airborne Gravity Gradiometry (AGG) results improved upon those of Bouguer gravity for the delineation of basement faults as well as structural fabric in the sedimentary section. The density and susceptibility variations of the basement from the modeling studies indicate that the change of crustal type from felsic to mafic lithologies. The high frequency component of the gravity gradient data is most likely related to the density variations within the upper sedimentary section, which would contribute for the velocity analysis of seismic data. Interpreted basement depths ranged from about $4 \mathrm{~km}$ in the south to about $13.5 \mathrm{~km}$ in the deepest part of the Lomas de Olmedo rift. The high resolution aeromagnetic and airborne gravity gradient data played an important role in corroborating with the seismic data for the mapping of the basement and to decipher the structural geometry.

\section{ACKNOWLEDGMENTS}

The authors are very much thankful to Marcos Amaral de Almeida for his vision and intelligent decisions made during the progress of this AGG Falcon project. They extend their thanks to Stephen Erck, FGMS for his help in this abstract preparation. The management of Petrobras and Fugro Gravity and Magnetic Services Inc. were acknowledged for granting permission to publish this abstract.

\section{REFERENCES}

Cominguez, A. H. and Ramos, V. A., 1995. Geometry and Seismic Expression of the Cretaceous Salta Rift System, Northwestern Argentina. In: Tankard A. J., 
Suárez R. S. and Welsink, H. J. (eds.) Petroleum basins of South America, AAPG Memoir, 62, 325-340.

Del Papa, C. E. and Salfity, J. A., 1999. Non-marine Paleogene sequences, Salta Group, Northwest Argentina. Acta Geologica Hispanica, 34 (2-3), 105-121.

Hernández, R., Disalvo, A., Boll, A. y Gómez Omil, R. 1999. Estratigrafía secuencial del Grupo Salta, con énfasis en las subcuencas de Metán-Alemania, Noroeste Argentino. En: González Bonorino, Omarini y Viramonte (Eds.): Geología del Noroeste Argentino, Relatorio $14^{\circ}$ Congreso Geológico Argentino, 1:263-283. Salta

Jacques, J. M., 2003. A tectonostratigraphic synthesis of the Sub-Andean basins: Implications for the geotectonic segmentation of the Andean Belt. Journal of the Geological Society, London, 160, 687-701.

Kley, J., Rossello, E. A., Monaldi, C. R. and Habighorst, B., 2005. Seismic and field evidence for selective inversion of Cretaceous normal faults, Salta rift, northwest Argentina. Tectonophysics, 399, 155- 172.

$\mathrm{Li}, \quad \mathrm{X} ., 2003$, On the use of different methods for estimating magnetic depth: The Leading Edge, 11, 10901099.

Marquilllas, R., C. del Papa, and I. Sabino. 2005. Sedimentary aspects and paleoenvironmental evolution of a rift basin: Salta Group (Cretaceous-Paleogene), northwestern Argentina. International Journal of Earth Sciences 94:94-113.

Ramos, V. A., 2008. The Basement of the Central Andes: The Arequipa and Related Terranes. Annual Review, Earth and Planetary Sciences, 36, 289-324.

Rapela, C. W., Pankhurst, R. J., Casquet, C., Baldo, E., Saavedra, J. and Galindo, C. 1998. Early evolution of the Proto-Andean margin of South America.Geology, 26 (8), 707-710. 